\title{
Membrane Markers, Target Cell Specificity, and Sensitivity to Biological Response Modifiers Distinguish Human Natural Cytotoxic from Human Natural Killer Cells
}

\author{
Marek Rola-Pleszczynski, Hien Lieu, Arthur K. Sullivan, and Marcel Girard \\ Immunology Division, Department of Pediatrics, Faculty of Medicine, University of Sherbrooke, Sherbrooke, Quebec, JIH 5N4, Canada; \\ and McGill Cancer Center, McGill University, Montreal, Quebec, Canada
}

\begin{abstract}
In the present report, we provide evidence for the distinct existence of a human natural cytotoxic (HNC) cell. This HNC cell can be identified by the monoclonal antibody HNC-1 A3 and by the absence of the T10 antigen, other antigenic markers being shared, at least in part, with natural killer (NK) cells, $\mathbf{T}$ cells, or monocytes. In addition, the HNC cell preferentially kills the MA-160 target, the herpes simplex virus-1-infected MA-160 cell line, and the two human tumor cell lines HEp-2 and HF-2. It has weak lytic activity against the NK-sensitive $\mathrm{K} 562$ cell line or its relatively NK-resistant clone I subline. The cytotoxic activity of the HNC cell is not augmented by interferon but is markedly enhanced by interleukin 2 and by a measles-virusinduced factor (MVF). Furthermore, it is not inhibited by cyclosporin A (CsA), in contrast to NK cell cytotoxicity against the $\mathrm{K562}$ target cell line which is augmented by interferon, inhibited by CsA, and not affected by MVF. These data suggest that spontaneously cytotoxic cells may belong to more than one subset of human lymphocytes, and that HNC cells may be defined in man using membrane markers, target cell specificity, and sensitivity to biological response modifiers.
\end{abstract}

\section{Introduction}

Peripheral blood lymphocytes (PBL) have been shown to spontaneously kill certain tumor target cells (1) as well as virus-infected autologous (2) and allogeneic cells (3). Human natural killer $(\mathrm{NK})^{1}$ cells that lyse the commonly used NK-sensitive K562 leukemia cell line have been well characterized, and are primarily large granular lymphocytes (4) that express receptors for the Fc portion of $\operatorname{IgG}(5)$ and certain cell surface markers (6-8). NK cell activity is augmented by interferon (IFN) (9), interleukin 2 (10), and leukotriene $B_{4}$ (11). In mice, a second distinct natural cytotoxic effector population has been described: murine natural cytotoxic (NC) cells primarily lyse nonlymphoid

Dr. Rola-Pleszczynski is a Scholar of the Fonds de Recherche en Santé du Québec.

Received for publication 18 December 1984 and in revised form 28 May 1985.

1. Abbreviations used in this paper: $\mathrm{ADCC}$, antibody-dependent cellular cytotoxicity; CsA, cyclosporin A; E/T, effector/target; FACS, fluorescenceactivated cell sorter; HNC, human natural cytotoxic; HNC-1A3, mouse monoclonal antibody defining HNC cells; HSV, herpes simplex virus; IFN, interferon; MVF, measles-virus-induced factor; NC, natural cytotoxic; NK, natural killer; PBML, peripheral blood mononuclear leukocytes.

J. Clin. Invest.

(c) The American Society for Clinical Investigation, Inc.

$0021-9738 / 85 / 11 / 1927 / 05 \quad \$ 1.00$

Volume 76, November 1985, 1927-1931 solid tumor cells and differ from NK cells in strain distribution of activity, expression of cell surface antigens, and sensitivity to interferon and interleukins $(12,13)$. We have recently produced a mouse monoclonal antibody (HNC-1 A3) which defines a subpopulation of human natural cytotoxic cells (14). In this report, we present new evidence that spontaneous cytotoxic activity in man is also mediated by at least two distinct lymphocyte subsets distinguishable from each other by target cell specificity, cell surface markers, and sensitivity to biological response modifiers.

\section{Methods}

Target cells and culture medium. All target cells were cultured and experiments were carried out at $37^{\circ} \mathrm{C}$ in a moisture-laden atmosphere of $5 \% \mathrm{CO}_{2}$ in air, using RPMI 1640 medium (Gibco Laboratories, Grand Island, NY) supplemented with $10 \%$ fetal calf serum (Gibco Laboratories) and $100 \mu \mathrm{g} / \mathrm{ml}$ gentamicin. Target cells employed were K562, a human erythroleukemia cell line; MA-160, a human prostatic adenoma cell line, which required anchorage for growth but could be lysed in suspension; HEp-2, the human laryngeal carcinoma cell line (Flow Laboratories Inc., McClean, VA); HF-2, a human melanoma cell line; and the MA-160 cell line persistently infected with herpes simplex virus type 1 (HSV). In some experiments, an NK-resistant subclone (clone I) derived from the K562 cell line was used (15). Moreover, for antibody-dependent cellular cytotoxicity (ADCC) assays, Raji targets cells were used with rabbit antiRaji IgG.

Effector cells. Peripheral blood mononuclear leukocytes (PBML) were isolated from the blood of normal healthy volunteers by separation on a Ficoll-Hypaque (Pharmacia Fine Chemicals, Inc., Piscataway, NJ) gradient. They consisted of $75-90 \%$ lymphocytes and $10-25 \%$ monocytes with $<1 \%$ polymorphonuclears. In specific experiments, PBML subsets were used as described below.

Identification and sorting of PBML subsets using monoclonal antibodies. The following monoclonal antibodies to human lymphocyte subsets were used: OKT4, OKT8, OKT10 (Ortho Pharmaceutical Corp., Raritan, NJ), Leu-7, Leu-11, and fluorescein-conjugated Leu-11 (Becton Dickinson, Sunnyvale, CA), and our own antibody HNC-1A3. For double marker studies, it was biotinylated for use with phycoerythrin-avidin (Becton Dickinson). Fluorescein-conjugated, affinity-purified $\mathrm{F}\left(\mathrm{ab}^{\prime}\right)_{2}$ goat anti-mouse Ig was purchased from Cappel Laboratories (Cochranville, PA). For identification of lymphocyte subpopulations, $1 \times 10^{6} \mathrm{PBML}$ were incubated with $5 \mu \mathrm{l}$ of antibody for $30 \mathrm{~min}$ at $4^{\circ} \mathrm{C}$, then washed and incubated with $\mathrm{F}\left(\mathrm{ab}^{\prime}\right)_{2}$ goat anti-mouse Ig (100 $\mu \mathrm{g}$ of $1 / 40$ dilution) for an additional $30 \mathrm{~min}$. After two washes in phosphate-buffered saline, cells were analyzed for fluorescence using a fluorescence-activated cell sorter (FACS 400, Becton Dickinson), with data collected on $5 \times 10^{4}$ viable cells.

PBML subsets bearing corresponding antigens were also sorted into positive $(+)$ and negative $(-)$ fractions using the FACS and respective monoclonal antibodies. In some experiments, antibody-labeled lymphocyte subsets were eliminated by addition of rabbit complement $(1 / 20$ dilution, Cedarlane Laboratories, Hornby, Ontario, Canada), leaving corresponding negative subsets for functional studies. In these experiments, PBML were sensitized with the respective monoclonal antibodies at $4^{\circ} \mathrm{C}$ for $60 \mathrm{~min}$ followed by addition of complement and incubation at $37^{\circ} \mathrm{C}$ for $60 \mathrm{~min}$. This was effective in removing $98 \%$ of the corresponding positive subset. When indicated, $\mathrm{HNC}-1 \mathrm{~A} 3^{+}$populations were 
prepared by the panning method. Antibody-labeled PBML were allowed to adhere to plastic petri dishes precoated with rabbit anti-mouse Ig for $1 \mathrm{~h}$. Nonadherent cells were removed by gently washing the plates, and they contained $<5 \% \mathrm{HNC}-1 \mathrm{~A}^{+}$cells. Adherent cells were removed by vigorously washing the plates, and they contained $>90 \% \mathrm{HNC}^{-1} \mathrm{A3}^{+}$ cells.

Biological response modifiers. Interferon- $\gamma$ (recombinant, Interferon Research), interleukin 2 (chromatography-purified, IFN- and lectin-free) and cyclosporin A (CsA, a generous gift from Dr. G. Holme, Sandoz Inc., East Hanover, NJ), were used as described. Measles-virus-induced factor (MVF) was produced by incubating $5 \times 10^{5} \mathrm{PBL}$ with $10^{5}$ measlesvirus-infected MA- 160 cells in a $200-\mu \mathrm{l}$ volume at $37^{\circ} \mathrm{C}$ for $4 \mathrm{~h}$ as described elsewhere (Girard, M., H. Lieu, and M. Rola-Pleszczynski, manuscript submitted for publication). Briefly, it is a lymphocyte product found in the supernatant of human lymphocytes co-cultured with measles-virus-infected cells, which is dialysable, heat-stable, and not destroyed by trypsin or chymotrypsin. It was shown to augment PBL cytotoxicity against the MA-160 target cell line at a 1/2-1/4 dilution.

Cytotoxicity assay. Cytotoxicity was measured by the ${ }^{51} \mathrm{Cr}$ release microassay; $5 \times 10^{3}$ target cells were used in each microtiter well with various numbers of effector lymphocytes, as indicated, so as to measure lysis on the linear portion of an effector:target $(E / T)$ ratio curve. After a 5-h incubation period, $100 \mu \mathrm{l}$ of supernatant was collected and cytotoxicity estimated from the released ${ }^{51} \mathrm{Cr}$ by counting in a gamma-counter (Nuclear-Chicago Corp., Des Plaines, IL). Percentage-specific ${ }^{51} \mathrm{Cr}$ release was calculated using the following formula:

Percent ${ }^{51} \mathrm{Cr}$ release

$=\frac{\text { experimental }- \text { spontaneous }{ }^{51} \mathrm{Cr} \text { released }}{\text { total releasable }{ }^{51} \mathrm{Cr}-\text { spontaneous }{ }^{51} \mathrm{Cr} \text { released }} \times 100$.

Statistical methods. Results were compared and analyzed for statistical significance using the Student's $t$ test for paired or unpaired values.

\section{Results}

Membrane markers of $N C$ cells. Since our original description (14) of a monoclonal antibody, HNC-1 A3, which defines human natural cytotoxic effector cells, these lymphocytes have been further studied using other monoclonal antibodies (Table I). $\mathrm{HNC}-1 \mathrm{~A}^{+}$cells were found to be negative for OKT10, Leu-7, and anti-HLA-DR, while $\sim 60 \%$ of them were labeled with Leu-11, a monoclonal antibody recognizing the Fc receptor. Their Fc receptor for IgG was also shown to be functional (Table II): $\mathrm{HNC}-1 \mathrm{~A} 3^{+}$cells were able to bind IgG-coated ox erythrocytes

Table I. Expression of Various Membrane Markers on Sorted HNC-1A3' Lymphocytes and on Unsorted PBML

\begin{tabular}{lll}
\hline & \multicolumn{2}{l}{ Percentage positive cells in } \\
\cline { 2 - 3 } Cell marker & Sorted HNC-1A3 & \\
\hline HNC-1A3 & $94 \pm 4$ & Unsorted PBML \\
E-rosettes & $30 \pm 6$ & $12 \pm 3$ \\
OKT4 & $6 \pm 1$ & $65 \pm 5$ \\
OKT8 & $17 \pm 6$ & $42 \pm 4$ \\
OKT10 & $<2$ & $23 \pm 3$ \\
Leu-7 & $<2$ & $12 \pm 2$ \\
Leu-11 & $58 \pm 5$ & $14 \pm 2$ \\
HLA-DR & $<2$ & $21 \pm 3$ \\
\end{tabular}

$\mathrm{HNC}-1 \mathrm{A3}^{+}$cells were sorted using biotinylated $\mathrm{HNC}-1 \mathrm{~A} 3$ (IgM) and phycoerythrin-avidin as fluorochrome. They were then analyzed for the fluorescein-labeled second marker using the FACS 400 cell sorter.
Table II. Presence of Fc Receptors for IgG and ADCC Activity of $\mathrm{HNC}-1 \mathrm{A3^{+ }}$ Cells

\begin{tabular}{|c|c|c|c|}
\hline \multirow[b]{2}{*}{ Population } & \multirow{2}{*}{$\begin{array}{l}\text { Rosettes with } \\
\text { IgG-coated ox } \\
\text { erythrocytes }\end{array}$} & \multicolumn{2}{|c|}{ ADCC cytotoxicitył } \\
\hline & & $E / T=50: 1$ & $E / T=25: 1$ \\
\hline & $\%$ & $\%$ & $\%$ \\
\hline PBL & $20 \pm 4$ & $79 \pm 6$ & $42 \pm 4$ \\
\hline $\mathrm{HNC}-1 \mathrm{~A} 3^{+}$ & $38 \pm 3^{*}$ & $56 \pm 5$ & $28 \pm 3$ \\
\hline $\mathrm{HNC}-1 \mathrm{~A} 3^{-}$ & $7 \pm 3$ & $84 \pm 7$ & $48 \pm 4$ \\
\hline
\end{tabular}

* Conversely $27 \pm 4 \%$ of $T$ cells bearing IgG Fc receptors $\left(T_{G}\right)$ and $8 \pm 2 \%$ of $\mathrm{T}_{\text {nong }}$ were $\mathrm{HNC}-1 \mathrm{A3}^{+}$.

$¥ \mathrm{ADCC}$ was measured by the amount of ${ }^{51} \mathrm{Cr}$ released from $5 \times 10^{3}$ Raji cells/well incubated with appropriate numbers of effector cells (as shown) in the presence of $1 / 40$ dilution of rabbit anti-Raji serum for $4 \mathrm{~h}$ at $37^{\circ} \mathrm{C}$. Cultures without antiserum showed $<2 \%$ cytotoxicity.

and were capable of killing Raji targets in the presence of antiRaji IgG antibody, albeit significantly less ( $30 \%)$ than either monocyte-depleted unfractionated PBML or the HNC-1 A3subset.

Interestingly, while $\mathrm{HNC}-1 \mathrm{~A} 3$ failed to label neutrophils or eosinophils, $75-80 \%$ of human peripheral blood basophils were labeled with this antibody, as determined in the FACS-sorted subpopulation.

Cold cell competition. Use of unlabeled cold cells in competition assays allowed us to identify two other cell lines, in addition to the MA-160 cell line, which would compete with each other but not with the NK cell target K562 line (Fig. 1). Both the HEp-2 and the HF-2 cell lines inhibited killing of MA160 targets while neither inhibited K562 killing, suggesting that different recognition structures or different effector cells were involved in the killing of K562 target on the one hand and MA-160, HEp-2, or HF-2 targets on the other.

Target cell specificity of $\mathrm{HNC}-1 \mathrm{A3}^{+}$cells. In order to further define the effector cells involved in these two kinds of cytotoxic activity, monocyte-depleted HNC-1A3-labeled PBL were either sorted using the FACS (Fig. 2) or panned on petri dishes previously coated with rabbit anti-mouse Ig (Fig. 3). The HNC$1 \mathrm{~A}^{+}$population was found to exert significantly less killing of K562 targets than unsorted PBML, whereas it was much more active than PBML in killing MA-160 targets, at all E/T cell ratios tested (Fig. 2). Moreover, the HNC-1 A3 ${ }^{-}$(or nonadherent) fraction was the main effector cell population in cytotoxicity directed at either the $\mathrm{K} 562$ cell line or clone I, a relatively resistant subclone of K562 (Fig. 3).

Sensitivity to biological response modifiers. In addition to membrane markers and target cell specificity, human natural cytotoxic (HNC) cells can be distinguished from classical NK cells by sensitivities to drugs and lymphokines. When PBML were preincubated with recombinant interferon- $\gamma$ for $1 \mathrm{~h}$ before the cytotoxicity assay, a significant augmentation of NK killing of K562 targets was observed as expected (Fig. 4). However, no significant change in MA-160 killing occurred, while cytotoxicity against HSV moderately but significantly decreased with interferon- $\gamma$ pretreatment. In contrast, interleukin 2 was effective in enhancing both HNC and NK cell activities against their respective target cells (Table III).

CsA, an antibiotic of fungal origin with immunosuppressive activity, significantly inhibited killing of K562 targets in a dose- 


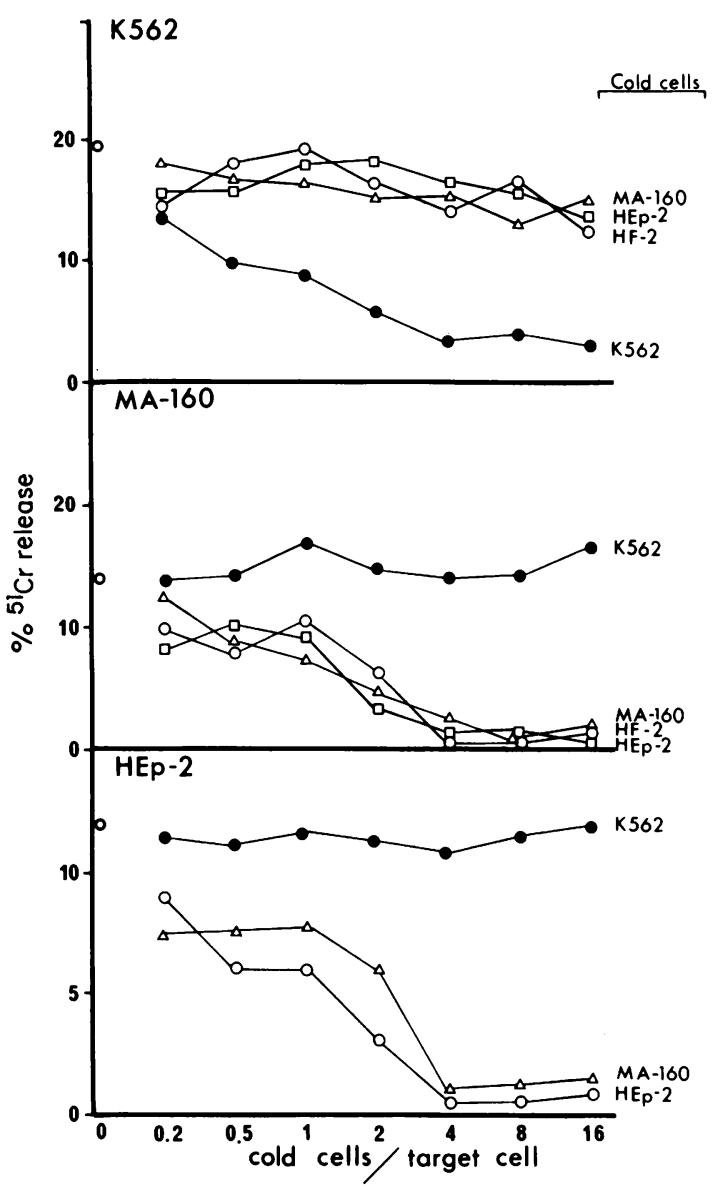

Figure 1. Cold cell competition assays using, as indicated, ${ }^{51} \mathrm{Cr}$-labeled K562, MA-160, or HEp-2 target cells incubated with PBL in the absence or presence of increasing numbers of unlabeled "cold cells."

dependent manner (Fig. 5). In contrast, no such inhibition was observed with HSV or MA-160 targets. On the other hand, MVF, which has a rapid and rather selective effect in augmenting $\mathrm{HNC}$ cytotoxicity against the MA-160 targets, produced no significant effect in HSV or K562 cytotoxicity assays (Fig. 6). Further distinction between MA-160 and K562 killing was observed when CsA and MVF were used together: MVF-augmented killing of MA-160 targets persisted in spite of CsA, while killing of K562 targets was progressively inhibited by increasing concentrations of CsA (Fig. 6). Moreover, killing of the HSV-infected target cell line was actually augmented in the presence of both CsA and MVF.

\section{Discussion}

Human NK cells have been shown to mediate spontaneous cytotoxicity against a variety of target cells (1). Most commonly, their cytotoxic activity is measured using the K562 erythroleukemia cell line, but NK cells can also kill allogeneic lymphoblasts, allogeneic (3) and autologous (2) virus-infected lymphoblasts, and some lymphoid and nonlymphoid tumor cell lines (16). It has thus been suggested that NK cells play an important role in host defenses against tumor growth and virus infections (1). Conversely, fresh human PBL rarely kill autologous tumor biopsy cells even after treatment of the PBL with IFN, which augments NK activity against allogeneic tumor cells (17). Further-
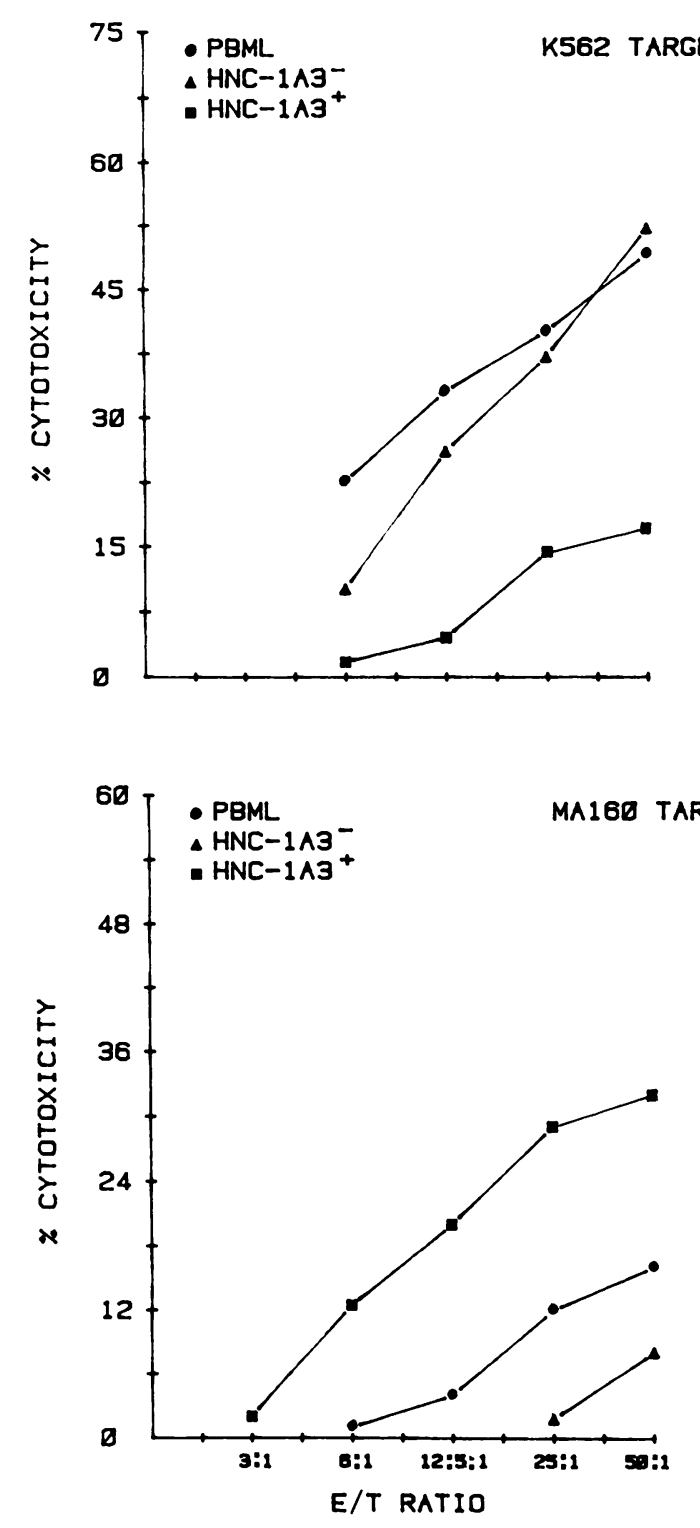

Figure 2. Cytotoxicity against K562 or MA-160 targets mediated by monocyte-depleted PBML or FACS-sorted $\mathrm{HNC}-1 \mathrm{~A} 3^{+}$or ${ }^{-}$subsets at various $\mathrm{E} / \mathrm{T}$ ratios. Data represent means of four experiments.

more, Fitzgerald et al. (3) and Lopez et al. (18) obtained evidence, which was based on membrane marker expression, cold target inhibition experiments, and patient studies, that NK cells lytic for K562 and virus-infected fibroblasts are at least partially nonoverlapping.

Similar findings in our laboratory led us to the development of HNC-1 A3 (14) which defines a subset of human natural cytotoxic lymphocytes that preferentially kill anchorage-dependent target cells rather than the K562 cell line. These findings suggested that $\mathrm{HNC}-1 \mathrm{~A} 3^{+}$cells may represent the human equivalent of murine NC cells (13), which are distinguishable from mouse NK cells in terms of cell surface markers, strain distribution, target cell specificity, and sensitivity to IFN or interleukins.

In analogy to murine NC cells, HNC cells represent a distinct lymphocyte subset. They express the HNC-1 A 3 antigen but not $(<2 \%)$ the HNK-1 (Leu-7) antigen characteristic of human NK cells (14). In further contrast to NK cells, HNC cells do not express the T10 (OKT10) antigen. On the other hand, some 


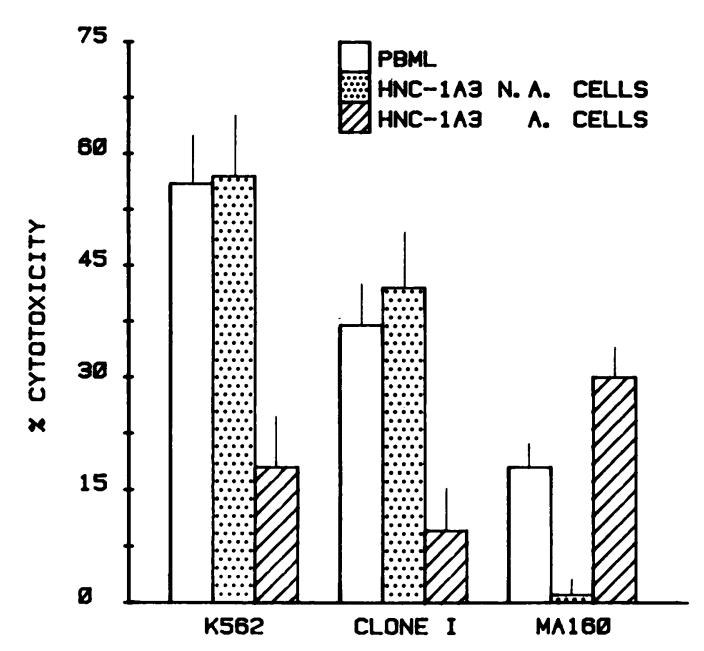

Figure 3. Cytotoxicity against K562, clone I, or MA-160 targets (E/T ratios of 50:1) mediated by monocyte-depleted PBML or panned HNC-1 A3-adherent (HNC-1 $\left.\mathrm{A3}^{+}\right)$or nonadherent (HNC-1 $\mathrm{A3}^{-}$) subsets. Data represent means \pm SEM of six separate experiments.

membrane markers are shared by NK and NC cells, or a fraction of either, such as Leu-11 (also shared by granulocytes), OKT8 (also shared by cytotoxic/suppressor T cells), or OKM1 (also shared by cells of myeloid origin). Morphologically, HNC cells are more heterogeneous than the predominantly large granular lymphocytes exhibiting most NK activity $(4,14)$.

A second set of distinct characteristics concerns target cell specificity. $\mathrm{HNC}^{+}$cells are the main effectors against the MA160 human prostatic adenoma cell line (14) as well as two other anchorage-dependent tumor cell lines (HEp-2 and HF-2), while purified Leu- $7^{+}$cells are quite inefficient against these targets. Conversely, $\mathrm{HNC}^{+}$cells lyse $\mathrm{K} 562$ targets significantly less than PBL or $\mathrm{HNC}^{-}$cells. Cold target inhibition experiments have suggested, in effect, that killers of K562 cells on the one hand, and MA-160, HEp-2, or HF-2 cells on the other, recognize and lyse their respective targets using distinct recognition sites. The

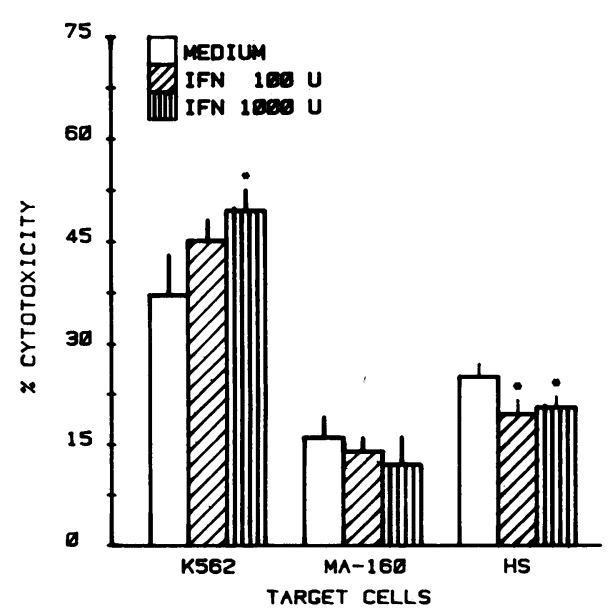

Figure 4. Cytotoxicity against K562, MA-160, or HSV-infected MA160 targets mediated by PBML that had been preincubated for $1 \mathrm{~h}$ in medium or in the presence of interferon PBML were then washed and added to the target cells (E/T ratio of 25:1) for a 5-h cytotoxicity assay. Data expressed as means \pm SEM. * Values significantly different from medium controls at $P<0.05$.
Table III. Effect of Preincubation With IL-2 on HNC and NK Cell Activities on Their Respective Target MA-160 and K562

\begin{tabular}{llll}
\hline & & \multicolumn{2}{l}{ Specific ${ }^{51}$ Cr release } \\
\cline { 3 - 4 } Effector cells & IL-2 & MA-160 & K562 \\
\hline \multirow{2}{*}{ PBML } & - & $15 \pm 3$ & $\%$ \\
& + & $26 \pm 4^{*}$ & $53 \pm 3$ \\
HNC-1A3 $^{+}$ & - & $22 \pm 2$ & $8 \pm 2$ \\
& + & $37 \pm 3^{*}$ & $13 \pm 2$ \\
HNK-1 $^{+}$ & - & $3 \pm 2$ & $37 \pm 4$ \\
& + & $5 \pm 2$ & $59 \pm 6^{*}$ \\
\hline
\end{tabular}

Effector cells were preincubated for $1 \mathrm{~h}$ with $5 \mathrm{U} / \mathrm{ml}$ of purified IL-2 (IFN- and lectin-free) before the addition to target cells at an $\mathrm{E} / \mathrm{T}$ ratio of 25:1. IL-2 was left throughout the 4-h cytotoxicity culture. Data represent means \pm SEM of three experiments. $* P<0.05$.

cell surface marker studies further suggest that these recognition sites are located on mostly nonoverlapping subpopulations.

A third set of characteristics distinguishing $\mathrm{HNC}$ and NK cells concerns their sensitivity to biological response modifiers. NK cell-mediated cytotoxicity has been shown to be augmented by IFN (9) and NK cells themselves can produce IFN. When cytotoxicity against uninfected MA- 160 cells was assayed in the presence of pure IFN, no significant change in cytotoxic activity of PBL was observed at conditions associated with enhanced killing of K562 targets. HSV-1-infected MA-160 cells were actually killed less in the presence of IFN than in its absence. Conversely, 5-h supernatants of measles-virus-pulsed $T$ cells significantly enhanced HNC killing of MA-160 targets, but were without effect on cytotoxicity of PBML against K562 targets. On the other hand, CsA has been shown to inhibit the generation of cytotoxic T and NK cells (19), and to reversibly inhibit NK cell activity (20). HNC cells not only were uninhibited by CsA, but their cytotoxicity could still be augmented by measles-virusinduced $\mathrm{T}$ cell supernatants in the presence of CsA. The mechanisms underlying this striking and unexpected effect of MVF and CsA are unknown at the present time.

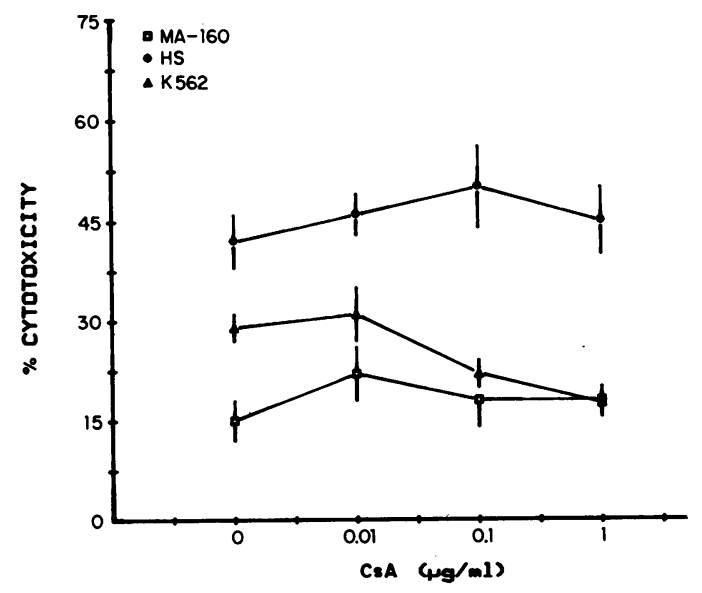

Figure 5. Cytotoxicity of PBML against MA-160, HSV-infected MA160 , or K562 targets (E/T ratios of 25:1) in the absence or presence of increasing concentrations of CsA. Values represent means \pm SEM. 


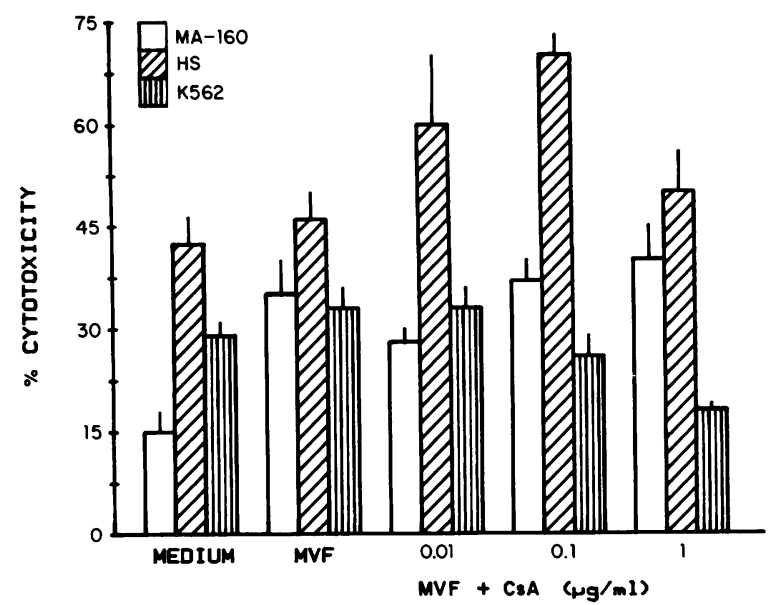

Figure 6. Cytotoxicity of PBML against MA-160, HSV-infected MA160 , or K562 targets (E/T ratios of 25:1) in the absence (medium) or the presence of MVF, with or without increasing concentration of CsA. Data represent means \pm SEM.

NK and NC cells share several properties, in both mouse and man: i.e., preexistence without induction in the normal host, lack of $\mathrm{H}-2$ or HLA restriction, and ability to lyse several tumor or virus-infected cell types. Other properties distinguish human and murine NC cells from NK cells, as illustrated in this report. Presently available data do not permit us, however, to answer the question of whether NC and NK cells derive from separate cell lineages or represent two variants or two activation or differentiation stages of a unique effector cell type.

The potential importance of defining the HNC subpopulation of human cytotoxic effector cells is twofold. Firstly, it may help explain and clarify some discrepancies that are being observed during NK cell studies, be they related to target cell specificity or responses to various immunomodulating factors (e.g., lack of response to IFN). Secondly, the availability of separate markers for HNC and NK cells, in terms of cell surface antigens and sensitivity to biological response modifiers, should allow for further exploration of the spontaneous cytotoxic activity of human PBL by permitting selective inhibition, activation, and sorting of $\mathrm{HNC}$ and NK effector cells. Such approaches may facilitate a greater intuition into the fine mechanisms controlling host defenses against viruses and tumors.

\section{Acknowledgments}

The authors acknowledge the expert secretarial assistance of Carole Jacques in the preparation of this manuscript.

This work was supported by grants from the Medical Research Council and the National Cancer Institute of Canada.

\section{References}

1. Herberman, R. B., T. Timonen, C. Reynolds, and J. R. Ortaldo. 1980. Natural Cell-mediated Immunity Against Tumors. R. B. Herberman, editor. Academic Press, Inc., New York. 89.
2. Yasukawa, M., and J. M. Zarling. 1983. Autologous herpes simplex virus-infected cells are lysed by human natural killer cells. J. Immunol. 131:2011-2016.

3. Fitzgerald, P. A., R. Evans, D. Kirkpatrick, and C. Lopez. 1983. Heterogeneity of human NK cells: comparison of effectors that lyse HSV1-infected fibroblasts and K562 erythroleukemia targets. J. Immunol. 130:1663-1667.

4. Timonen, T., J. R. Ortaldo, and R. B. Herberman. 1981. Characteristics of human large granular lymphocytes and relationship to natural killer and K cells. J. Exp. Med. 153:569-582.

5. Kay, N. D., G. D. Bonnard, W. H. West, and R. B. Herberman. 1977. A functional comparison of human Fc-receptor-bearing lymphocytes active in natural cytotoxicity and antibody-dependent cellular cytotoxicity. J. Immunol. 118:2058-2066.

6. Zarling, J. M., K. A. Clouse, W. E. Biddison, and P. C. Kung. 1981. Phenotypes of human natural killer cell populations detected with monoclonal antibodies. J. Immunol. 127:2575-2580.

7. Abo, T., and C. M. Balch. 1981. A differentiation antigen of human NK and K cells identified by a monoclonal antibody (HNK-1). J. Immunol. 127:1024-1029.

8. Perussia, B., S. Starr, S. Abraham, V. Fanning, and G. Trinchieri. 1983. Human natural killer cells analyzed by B73.1, a monoclonal antibody blocking Fc receptor functions. J. Immunol. 130:2133-2141.

9. Saksela, E., T. Timonen, and K. Cantell. 1979. Human natural killer cell activity is augmented by interferon via recruitment of "preNK" cells. Scand. J. Immunol. 10:251-266.

10. Henney, C. S., K. Kuribayashi, D. E. Kern, and S. Gillis. 1981. Interleukin-2 augments natural killer cell activity. Nature (Lond.). 291: 335-338.

11. Rola-Pleszczynski, M., L. Gagnon, and P. Sirois. 1983. Leukotriene B4 augments human natural cytotoxic cell activity. Biochem. Biophys. Res. Comm. 113:531-537.

12. Stutman, O., C. J. Paige, and E. F. Figarella. 1978. Natural cytotoxic cells against solid tumors in mice. 1. Strain and age distribution and target cell susceptibility. J. Immunol. 121:1819-1826.

13. Lattime, E. C., G. A. Pecoraro, and O. Stutman. 1983. The activity of natural cytotoxic cells is augmented by interleukin 2 and interleukin 3. J. Exp. Med. 157:1070-1075.

14. Rola-Pleszczynski, M., and H. Lieu. 1983. Human natural cytotoxic lymphocytes: definition by a monoclonal antibody of a subset which kills an anchorage-dependent target cell line but not the K562 cell line. Cell. Immunol. 82:326-333.

15. MacDougall, S. L., C. Shustik, and A. K. Sullivan. 1983. Target cell specificity of human natural killer (NK) cells. 1. Development of an NK-resistant subline of K562. Cell. Immunol. 76:39-48.

16. De Landazuri, M. D., M. Lopez-Bolet, T. Timonen, J. R. Ortaldo, and R. B. Herberman. 1981. Human large granular lymphocytes: spontaneous and interferon-boosted NK activity against adherent and nonadherent tumor cell lines. J. Immunol. 127:1380-1383.

17.Vanky, F. T., S. A. Argov, S. A. Einhorn, and E. Klein. 1980. Role of alloantigens in natural killing. J. Exp. Med. 151:1151-1165.

18. Lopez, C., D. Kirkpatrick, P. A. Fitzgerald, C. Ching, R. N. Pahwa, R. A. Good, and E. M. Smithwick. 1982. Studies of the cell lineage of the effector cells that spontaneously lyse HSV-1 infected fibroblasts (NK(HSV-1)). J. Immunol. 129:824-828.

19. Landegren, U., U. Ramstedt, I. Axberg, A. Orn, and H. Wigzell. 1981. Cyclosporin A permits the distinction between specific $T$ and NK activity generated in a human MLC. Int. J. Cancer. 28:725-730.

20. Introna, M., P. Allavena, F. Spreafico, and A. Mantovani. 1981. Inhibition of human natural killer activity by cyclosporin A. Transplantation. 31: 113-116. 